\title{
On Investigation of Metals Composition in Old Chinese Coin from the Northern Song Dynasty Found in Bali Island Indonesia
}

\author{
Tjokorda Udiana Nindhia Pemayun and Tjokorda Gde Tirta Nindhia
}

\begin{abstract}
It is unique to inform that in the small island of Bali, located at central Archipelago Country of Indonesia, the old Chinese coin have an important value as component of the ritual and culture. Until the end of the XIX Century, the old Chinese coin still have its function as a currency in Bali Island and later the function as a currency is no longer applicable since Rupiah currency now as legal currency in the Bali Island as a part on Indonesia country. But its function for ritual and culture are still remaining. Since the fabrication of old Chinese coin was in China and also its production is not continued at the recent day causes the Balinese peoples difficult to obtain it. An effort to produce a local made Chinese coin is then promoted but the result is not satisfaction because the appearance especially the color is not mach with the original one due to metal composition of old Chinese coin is not recognize. The old Chinese coins that are found in Bali are recognized come from several dynasties in China. For this purpose one by one of the old Chinese coin which are depend of the dynasty that produce the coin should be investigated. In this article, the old Chinese coin from Northern Song Dynasty was investigated in order to explore its metal composition so that possible for local peoples to produce it in Bali as a local made. It is found that the metal composition of the northern Song Dynasty of old Chinese coin that was found in Bali island are made of copper $(\mathrm{Cu})$ that reach about $62.221 w t . \%$ followed by tin (Sn) about $22,98 \mathrm{wt} . \%$ and lead $(\mathrm{Pb})$ about $6.644 \mathrm{wt} \%$. Surprisingly that the coin just contain about 0.238 wt.\% zinc $(\mathrm{Zn})$ that mean the coin is in category as a bronze and not as a brass. Other trash element that are found are iron ( $\mathrm{Fe}$ ) about $2.611 \mathrm{wt} . \%$, vanadium $(\mathrm{V})$ about 0.062 wt. \% and also titanium (Ti) about 0.424 wt. \% as supported by metallography analyses.
\end{abstract}

Index Terms - Chinese, coin, Bali, dynasty, song.

\section{INTRODUCTION}

The unique cultures of Bali as well as the beauty of the Island make it as favorite tourist destination. Thousand of visitor visit this small island to enjoy the interesting and fascinating object of tourism. One of the interesting of the Balinese culture to be discussed here is about the used of old Chinese coin as a part of their offering during practicing of their ritual believe and also the use of the Chinese coin in the Balinese culture. Fig. 1 is an example of application of old

Manuscript received June 27, 2013; revised August 27, 2013.

Tjokorda Udiana Nindhia Pemayun is with the Department of Fine Visual Arts (Jurusan Seni Rupa Murni), Indonesia Arts Institute Denpasar, J1. Nusa Indah, Denpasar, Bali, 80235, Indonesia (e-mail: nindhia@yahoo.com).

Tjokorda Gde Tirta Nindhia is with the Industry Manufacture and Machinery Research Group. Department of Mechanical Engineering, Engineering Faculty, Udayana University, Jimbaran, Bali, 80361, Indonesia (e-mail: tirta.nindhia@me.unud.ac.id).
Chinese coin as part of the offering during praying. It is interesting that in Fig. 1 we can see the use of modern paper money to complete the offering but still beside that, the binding of old Chinese coin is presented. Other examples is in the Fig. 2, the special offering presented during celebration for the new baby born. A binding of old Chinese coin as a part of the offering together with rice, egg and onion.

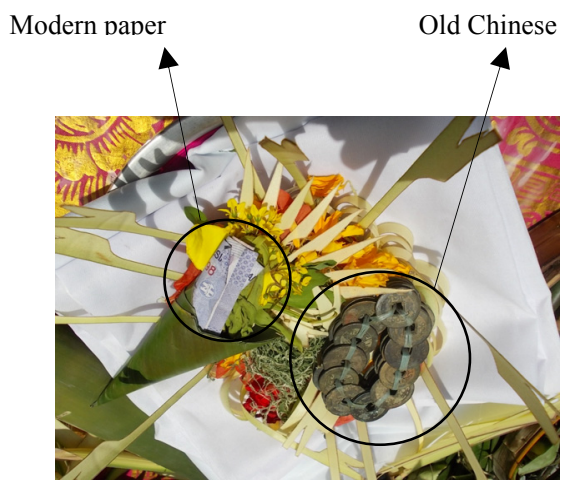

Fig. 1. Example of offering that using old Chinese coin in Balinese ritual

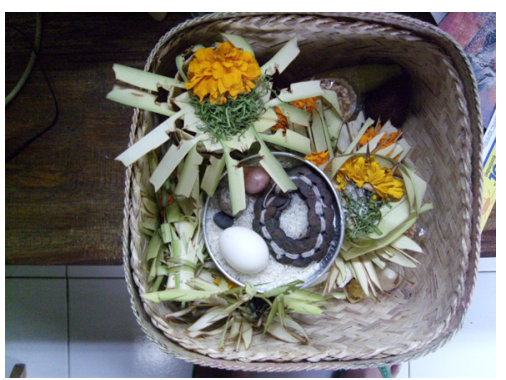

Fig. 2. Example of the offering that using old Chinese coin in Balinese ritual. The coin binding together with rice, egg and onion presented for the protection of the baby from the bad evil.

The local peoples in Bali Island also use the old Chinese coin to make a sacred figure of object of prayer particularly for The Gods of money which is called Bhatara Rambut Sedana. These sacred figure are appear as a couples of character of man and women which is made form old Chinese coin as presented in Fig. 3.

In the history that related to Bali Island, there is no any proof that this small island in the past was being part of Chinese Imperial. But it is there is a legend telling about certain king of Bali which his queen is Chinese origin. This article is not focused on history of the way how old Chinese coins reached Bali island but mainly addressed to the now day existence of old Chinese coin in Bali that having special value in the heart and feeling of Balinese peoples. Unfortunately the existence of the coins itself day by day are become more difficult to find since it is no longer produced in China. 


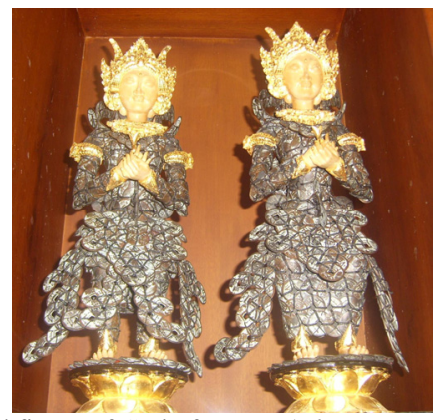

Fig. 3. The sacred figure of God of money (Bhatara Rambut Sedana). The figures appear as a couples man and woman which are made almost entirely from old Chinese coin.

The old Chinese coins its self were found come from different dynasty in China as presented in Fig. 4. The type of the old Chinese coin can be differentiated by Chinese characters that are written in the coin and also by the antique color that appear in the surface. Some of the coin give color of yellow to black, green to black, white to black and so on which is mean that every coin having difference metals composition depend of which dynasty its coming from.

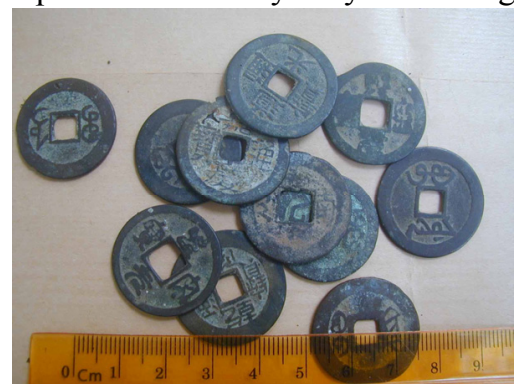

Fig. 4. Old Chinese coins from several dynasties that are used in Bali Island for ritual and culture purposes.

(a)

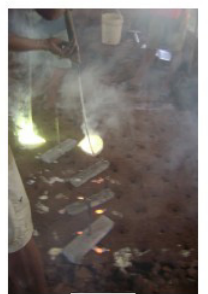

(c)
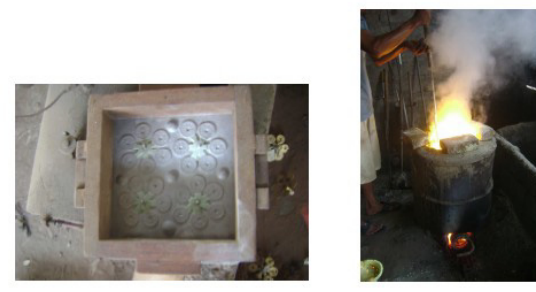

(b)

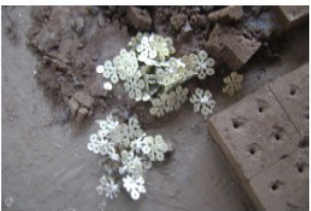

(d)

Fig. 5. Reproduction of old Chinese coin activity in Bali Island. (4a) is the mould for casting the coin. (4b) is preparing the molten copper alloy and (4c) is casting metal process, finally (4d) reproduction of old Chinese coin is obtained.

In our previous research [1], the metal composition of old Chinese coin from Qing dynasty that was found in Bali island already discovered completed with explanation of the metallurgical aspect of the coin. The information that was offered from previous research already used by the local made Chinese coin in Bali Island in order to get the same appearance with the real old Chinese coin from Qing dinasty. Fig. 5 are some pictures to describe the activity of producing the copy of old Chinese coin in Bali to supply the demand of the coin for the ritual and culture purpose in Bali Island. Fig. $4 \mathrm{a}$ is the mould for casting the coin. Figure $4 \mathrm{~b}$ is preparing the molten copper alloy and Fig. 4c is casting metal process. Finally reproduction of old Chinese coin is obtained (Fig. 4d).

In this article, the coin from Northern Song Dynasty found In Bali Island Indonesia will be used as an object of investigation to investigate its metal composition in order possible to be reproduced as local made Chinese coin in Bali

\section{EXPERIMENTAL}

The original Old Chinese coin from Northern Song Dynasty found In Bali Island Indonesia as presented in Fig. 5 was used as an object of the investigation. Northern Song dynasty [2] beginning from the years of 960 until 1125. The Northern Song dynasty was one of the most productive dynasties, with respect to the issuing of different variations of bronze cash coins. Even more than its abundance, the quality and aesthetic value of the Song coins are highly appreciated. The standardized sizes and 4-character pattern on the obverse, The reverse of a coin during the Song-dynasty was empty, with very few exceptions (mostly nail marks or a dot and at one occasion the designation of the place of minting [2]. This coin can be recognized from the script appeared in the obverse side (front side) which is reading from the top and next character is in the direction of clock wise [3]. In full, the scripts are sound as Zhi Dao Yuan Bao which is Zhis Dao is the name of the emperor and Yuan Bao mean original curency [3]. The reverse side (back side) is plain or no script found.

The nature of the metal or alloy employed to make the object. For example, many debased silver objects are made from silver-copper alloys and both constituents are clearly visible in the polished and etched section; they show up as a copper-rich phase and as a silver-rich phase. Sometimes it may be very difficult to obtain any idea of composition from looking at the microstructure and here additional evidence must be obtained using a suitable analytical method. One way of doing this if a sample has been taken and already mounted is to trim the plastic mount and place the sample [4]. In an $\mathrm{X}$-ray fluorescence analyzer (XRF) .X- ray fluorescence (XRF) technique was utilized in this research to identify the metal composition of the coin. This technique is utilized the $\mathrm{X}$ - ray emission characteristic from the secondary electron (fluorescent) which is exited because of the energy hit of Xray from external source. The energy that is emitted is the typical characteristic of specific atom of the element.

Metallography investigation was conducted on the specimen for further analysis. Metallography is a tool that can provide information about fabrication process and treatment during manufacturing. The metallography technique can explain for example the object was casting or by forging. The change on microstructure of metallography can be used to explain the thermal treatment during manufacturing. The natures of alloys are specific that can be used to identify certain type of alloy [4]. The metallography techniques involve series of activities started from mounting, 
grinding, polishing, etching and finally observation on metallurgical microscope for microstructure recorded by camera.(See Fig. 6).

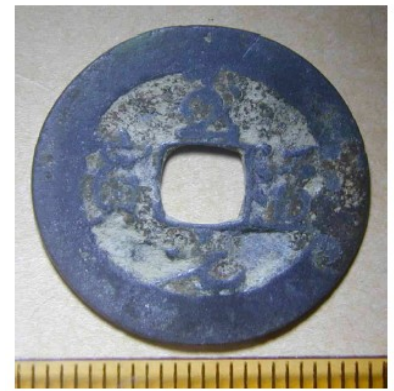

(a)

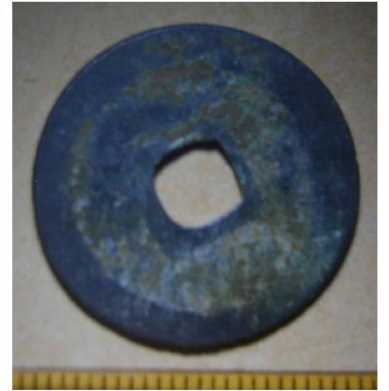

(b)
Fig. 6. Northern Song Dynasty old Chinese coin that is investigates in this research. (a) Obverse side and (b) reverse side.

Mounting was done by encapsulating the specimen in a polymeric material. Once mounted and set, the resin block must be ground flat. The standard procedure at this stage is to use wet silicon carbide papers with progressively finer grit sizes [4].

In the step of polishing, the best results are to be obtained by polishing on diamond-impregnated rotary polishing wheels lubricated with mineral oil. Diamond powders are usually supplied as tubes of paste or in aerosol cans in an oil-based suspension.

In order to examine grain boundaries, other phases, and effects of alloying additions the polished metal surface must be attacked with selected chemical reagents that will reveal differences in grain orientation and microstructure. For this purpose to solution of: Aqueous ferric chloride: $120 \mathrm{ml}$ distilled water $\left(\mathrm{H}_{2} \mathrm{O}\right), 30 \mathrm{ml}$ hydrochloric acid $(\mathrm{HCl}), 10$ 9ram ferric chloride $\left(\mathrm{FeCl}_{3}\right)$, With Etching time is given as a few minutes [4].

All examinations of microstructure should begin with use of the light microscope, starting at low magnification, such as $100 \times$, followed by progressively higher magnifications for efficient assessment of the basic characteristics of the microstructure [5].

\section{RESUlT AND DISCUSSION}

From XRF analyzes is obtained that the mayor composition is copper $(\mathrm{Cu})$ that reach about $62.221 \mathrm{wt} \%$ followed by Tin ( $\mathrm{Sn})$ about 22.98 wt. \% and lead $(\mathrm{Pb})$ about $6.644 \mathrm{wt} \%$. Surprisingly that the coin just contain about $0.238 \mathrm{wt} \%$ zinc $(\mathrm{Zn})$ that mean the coin is in category as a bronze and not as a brass which is agree with information provided by Schjöth [2] and Glahn [6]. Other metal elements that are found are Iron (Fe) about $2.611 \mathrm{wt} \%$, Vanadium (V) about $0.062 \mathrm{wt} \%$ and also Titanium (Ti) about $0.424 \mathrm{wt} \%$ as can be seen at Table 1. This result give information that the old Chinese coin from Northern Song dynasty found in Bali, Indonesia have different composition which old Chinese coin from Qing dynasty that already discovered in our previous publication [1], which is also agree with the report from Furtado et al. [7] that the Qing dynasty coin is in category brass but Northern Song dynasty is in category of bronze. Related with old Chinese coin from other region in the world, at British Museum for example [8], the metal composition is also found in the category of bronze which is also content less amount of zinc comparing the tin, but it is interesting to discus here that the coin of Northern Song dynasty in the British museum contain less amount of tin which is around $13-15 \mathrm{wt} \%$ mean while the coin found in Bali, Indonesia contain about $22.498 \mathrm{wt} \%$ of tin.

The song dynasty was a golden age of coin casting in term of the enormous quantity of coins produced, their variety, the precision of the alloy composition and the great technical skill employed. It is informed that in the history of the Song Dynasty, over 5000 million bronze coins were produced. The major change in coinage from bronze to brass in china occurred during the early part of the $16^{\text {th }}$ century. This change over was almost certainly prompted by economics [8].

TABLE I: COMPOSITION OF METAL IN THE NORTHERN SONG DYNASTY OLD CHINESE COIN FOUNDS IN BALI, INDONESIA

\begin{tabular}{|l|l|}
\hline \hline Metals & Wt \% fraction \\
\hline $\mathrm{Sn}$ (Tin) & 22.498 \\
\hline $\mathrm{Pb}$ (Lead) & 11.353 \\
\hline $\mathrm{Zn}$ (Zinc) & 0.238 \\
\hline $\mathrm{Cu}$ (Copper) & 62.221 \\
\hline $\mathrm{Fe}$ (Iron) & 2.611 \\
\hline $\mathrm{Ti}$ (Titanium) & 0.424 \\
\hline $\mathrm{V}$ (Vanadium) & 0.062 \\
\hline \hline
\end{tabular}

Metallographies analyses reveal that the microstructure is containing with pore which is indication that manufacturing process come from casting method and not by using forging or struck with hammering. For casting Chinese coins alloy should be suitable for casting method of production. Essentially two types of alloys were use to manufacture old Chinese coins: tin bronze up to 16th century and the brass until the early 19th century. For The whole of this period whether bronze or brass was used, both of these alloys were leaded. The used of lead alloy was partly influenced by cost and has been a major consideration [8].

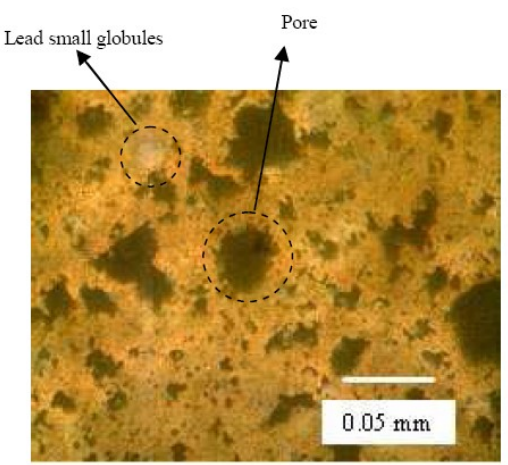

Fig. 7. Microstructure of lead tin bronze from old Chinese coin of Northern Song dynasty found in Bali Island, Indonesia

There are advantages in producing coins by casting rather than striking. The process of casting no need much work for labour and requires less skilled personnel [8].

The metallography analyzes (see Fig. 7) also proof that the coin of the Northern Song dynasty is not made from brass since the microstructure is not representative of the brass microstructure but appear as tin bronze that are leaded $(\mathrm{Pb}$ addition). Lead is not alloy with copper or tin and appear in the microstructure as small globules throughout the structure [4]. It should be noted that small amount of Vanadium (V) is detected in the coin which is not found in Northern Song 
dynasty coin collection of British Museum [8].

The addition of lead to bronze or brass yield two important effects: will reduce the solidification temperature and significantly increase the fluidity of molten metal. These two benefits are required in manufacture of small detailed pattern by casting. The use of leaded alloy was partly influenced the cost and availability of metals. Their technical suitability is also major consideration [8].

\section{CONCLUSION}

The old Chinese coin from the Northern Song dynasty that is found in Bali Island Indonesia is from the bronze type of alloy which also reach with lead $(\mathrm{Pb})$ to form lead tin bronze. The coin is made trough the casting process. This information can be used to reproduce the Chinese coin in order to obtain similar appearance with the origin coin.

\section{ACKNOWLEDGMENT}

This work mainly using equipment of archaeometallurgy tools belong to the Research Group of Industry, Manufacture and Machinery Udayana University, Bali, Indonesia to where the acknowledgment should be addressed.

\section{REFERENCES}

[1] T. U. N. Pemayun and T. G. T. Nindhia, "Visual and non-visual aesthetic of old Chinese coin found in Bali Island, Indonesia," Journal of Bahasa dan Seni, vol. 39, no.1, 2011, pp 59-67, February 2013.

[2] F. Schjöth, Chinese Currency. The Currency of the Far East, Yellow Dragon Productions, Holland, 2007, ch. 5, pp.1-10.

[3] D. Hartil, Cast Chinese Coins, Trafford Publishing, USA, 2005, ch.2, pp. 125-159.

[4] D. A. Scott, Metallography and Microstructure of Ancient and Historical Metals, the Getty Conversation Institute, Singapore, 1991, ch. 4, pp. 25-29

[5] G. F. V. Voort, Metallography and Microstructures, ASM Handbook, U.S.A., 2004, ch. 3, pp.589-912.

[6] R. V. Glahn, "Silver and the transition to a paper money standard in song dynasty (960-1276) China," UCLA, 2010, ch.1, pp 1-32.
[7] M. J. Furtado, R. J. C. Silva, M. F. Araujo, and F. M. B. Femandes, "Composition and microstructure of imperial brass Chinese coins," Material Science Forum, vol. 636-637, pp. 531-537, January 2010.

[8] J. Turquet, Metallurgical Analysis of Chinese Coins at the British Museum, British Museum Press, London, 2005, ch. 4, pp. 69-83.

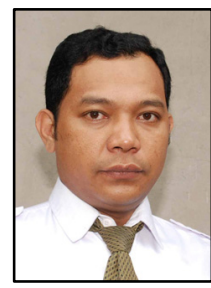

Tjokorda Udiana Nindhia Pemayun was born in Denpasar, Bali, Indonesia on February $26^{\text {th }} 2073$. Received doctor degree in culture study from Udayana University on 2009. His current job is as a lecturer and researcher at Denpasar Indonesia Arts Institute (Institute Seni Indonesia Denpasar/ISI Denpasar) Bali, Indonesia. He regularly teaches subject of: Sculpture Review, The History f Indonesia Visual Arts, Sculpture, The Arts of Balinese Culture, Intellectual Properties Right, and Sculpture Material.

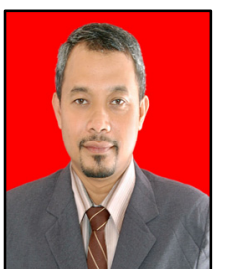

Tjokorda Gde Tirta Nindhia was born in Denpasar, Bali, Indonesia on January $16^{\text {th }}, 1972$. Received doctor degree in mechanical engineering from Gadjah Mada University (UGM) Yogyakarta, Indonesia on August 2003, with major field of study was Material Engineering.

He participated in various international research collaboration such as with Muroran Institute of Technology Japan (2004), Toyohashi University of Technology Japan (2006), Leoben Mining University Austria (2008-2009), Technical University of Vienna Austria (2010) and Recently with Institute Chemical Technology of Prague Czech Republic (2012-now). His current job is as Full Professor in the field of Material Engineering at Department of Mechanical Engineering, Engineering Faculty, Udayana University, Jimbaran, Bali, Indonesia. His research interest covering subjects such as, biomaterial, waste recycle, failure analyses, ceramic, metallurgy, composite, renewable energy, and environmental friendly manufacturing.

Prof. Nindhia is a member of JICA Alumni, ASEA-UNINET alumni, and also member of association of Indonesian Nanotechnology. Prof Nindhia received best researcher award in 1997 and in 2013 from Udayana University the place where he is working and again in 2012 received both Best researcher award from Engineering Faculty of Udayana University . In 2013 Prof Nindhia awarded as 15 best performance Indonesian lecturers from Ministry of Education and Culture The Republic of Indonesia 